\title{
THE ENGAGEMENT OF THE VISEGRAD 4 IN INTERNATIONAL TRANSFER OF CAPITAL IN THE FORM OF FOREIGN DIRECT INVESTMENT IN THE POST-CRISIS PERIOD
}

\author{
IwONA PAWLAS ${ }^{1}$ \\ University of Economics in Katowice (Poland)
}

\begin{abstract}
The paper concentrates on the international transfer of capital in the form of foreign direct investment (FDI). A relatively high level of investment attractiveness of an economy is required for the attraction of capital in the form of FDI. Inflow of capital in the form of FDI is perceived as a factor stimulating economic development of the so-called catching up economies, and the Visegrad 4 countries can be viewed as such economies. The crucial objective of the paper is to present investment attractiveness of the Visegrad 4 countries in the light of the International Bank for Reconstruction and Development / the World Bank reports and EY's surveys. A parallel objective is to analyse the engagement of the Visegrad 4 countries in international capital transfer in the form of FDI in post-crisis period in order to identify inward and outward FDI flows and stock. The research tools used in the article included literature studies, descriptive analysis and comparative analysis. The undertaken research leads to a conclusion that foreign capital played an important role in the transformation of the V4 economies and their strong integration with the world economy. It contributed to supplementing capital shortages and increasing efficiency. The V4 countries remain net importers of capital in the form of FDI, though the positions of the V4 as investors in the world market have risen slightly over the last decade. It is of vital importance to introduce dynamic and effective actions aiming at promoting the V4 as a location of FDI and to undertake parallel activities directed at stimulating the V4 investment abroad.
\end{abstract}

KEY WORDS: international transfer of capital, foreign direct investment, the Visegrad 4 countries.

JEL CODES: F21, F23, F02, O57.

DOI:

\section{Introduction}

The intensity of economic relations and links in the global economy of the $21^{\text {st }}$ century gets higher and higher. International transfer of capital constitutes an important element stimulating international economic integration between and among national economies: the Visegrad 4 countries have participated actively in the international transfer of capital since the beginning of the 1990s when they initiated the process of socioeconomic and political transition. The overall picture of the globalized economy has become much more complicated due to global financial crisis 2008+ which hit most European economies, including the Visegrad countries.

\footnotetext{
Iwona Pawlas - PhD, professor at the Department of International Economic Relations, University of Economics in Katowice, Poland

Scientific interests: expert in the field of international economics, international business, European Union integration processes; author and co-author of more than 130 scientific publications in Polish and English (monographs, chapters in monographs, articles and conference papers)

E-mail: iwona.pawlas@ue.katowice.pl

Tel. +48322577854
} 
The problem of research. The main problem of this article is the exploration and evaluation of the scale of the Visegrad 4 countries' participation in international transfer of capital in the form of foreign direct investment (FDI) in the post-crisis period both in regard to import of capital and export of capital.

The aim of research. The article aims at presenting the investment attractiveness of the Visegrad 4 countries as well as evaluating the actual level and intensity of inflow of FDI into the Visegrad 4 countries and export of capital in the form of FDI by the Visegrad 4 countries from 2007 to 2017.

The object of research is the Visegrad 4 countries, i.e., Poland, Hungary, Slovakia and the Czech Republic. The research was conducted based on the data of the years 2007-2017.

The tasks of research: 1) to identify theoretical aspects of foreign direct investment as a special form of international transfer of capital; 2) to gather statistical information regarding inflow and outflow of capital in the form of FDI in the Visegrad 4 countries; 3) to explore and diagnose the situation in the analysed subjects in terms of: investment attractiveness, FDI flows, FDI stock in comparison to and against the background of the European Union.

The methods of research. The research tools used in the article included literature studies, descriptive analysis and comparative analysis. Statistical material provided by UNCTAD and taken from the World Investment Reports was also used for the analysis; additionally, reports published by Ernst \& Young / EY were studied.

1. Foreign direct investment as a specific form of international transfer of capital: theoretical aspects

International transfer of capital constitutes an important element of international economic relations. According to a broad definition international transfer of capital is "any movement of capital across border", while a narrow definition states that "export of capital is export of value in order to earn value added" (Budnikowski, 2001: 137). The reasons for export of capital include: differences in interest rates, lack of possibility to invest capital at home, need to avoid barriers like tariffs, quantitative and qualitative restrictions, wish to control some sector of the economy in capital importing country, desire to take advantage of lower costs of labour, raw materials or land, wish to take advantage of not so strict regulations in destination country (e.g., concerning environmental protection), need to reduce the development of "dirty" industries at home (Klave, Makać, 1987: 213-216). Hence, both pull and push factors should be taken into consideration when international capital flows are concerned. In literature on the subject, one can find plenty of classifications of international transfer of capital. According to the period of time, international transfer of capital is classified into: short-term transfer of capital (up to one year) and long-term transfer of capital (capital is exported for the period longer than one year) (Rodrik, Velasco, 1999: 1-30; Piklikiewicz (ed.), 2001: 73, 80). As far as the source of capital is concerned, international transfer of capital is classified into: public capital (government budget, local budgets, intergovernmental organizations), private capital (enterprises, commercial banks, individuals) and capital of international organizations. When it comes to the form of capital exported, international transfer of capital is divided into: production capital (equity finance) and capital lending and borrowing (debt finance). Moreover, production capital is divided into: foreign indirect investment and foreign direct investment. Foreign indirect investment, the so-called foreign portfolio investment takes the form of investment in ownership of firms through buying their shares or bonds; foreign portfolio investment does not guarantee the possibility to significantly influence and/or control the foreign enterprise. Foreign direct investment means international capital flows in which a firm from one country creates or expands a subsidiary in another. The distinctive feature of foreign direct investment is that it involves not only transfer of resources but also the possibility to significantly influence and/or control of a foreign enterprise. Hence, the main motivation of the direct investor is to obtain some degree of influence over the management of its direct investment enterprise. Foreign direct investment can be further divided into: greenfield and brownfield investment (Krugman, Obstfeld, 2003: 675-676; OECD, 2008: 22). 
Undoubtedly, international transfer of capital is a key aspect of the international monetary system. It provides significant benefits for countries (both net exporters and net importers of capital). One should, however, note that international capital flows can also carry risks for macroeconomic and financial stability, and pose challenges for national economies and policies (IMF, 2016: 1-4).

Effects of the export of capital should be analysed separately for a capital importing country and a capital exporting one. In case of the capital exporting country, the following effects should be taken into consideration:

- worsening the balance of payments in the short run;

- fewer potential jobs (if the capital could be invested at home);

- in the long run production of the foreign enterprise may substitute home production (that means rising imports and fewer jobs);

- the balance of payments should be improved in the long run;

- the rise in employment may occur if export of components to a foreign branch is necessary;

- the rise of exports of machinery, equipment, raw materials and semi-products,

- entering new markets and overcoming barriers of insufficient demand (Feldstein, Horioka, 1980: 314-329).

Effects of the import of capital are even more complex: one should analyse separately the effects of the inflow of capital into developed countries and developing (or underdeveloped) ones. When it comes to the developed countries, inflow of foreign capital usually results in:

- inflow of technologies;

- increased investment funds in neglected regions;

- fighting monopolies predominant at home;

- but even here home economy may be dominated by foreign capital and foreign enterprises do not take into account the hostage-country's interests.

Regarding developing and underdeveloped countries, the import of capital: brings rising investment fund, results in higher employment and production, creates the effect of the improvement of the balance of payments in the short run (due to the inflow of capital itself). In the long run (due to rising exports), it stimulates the inflow of modern technologies. One should, however, note that the inflow of foreign capital into the developing or underdeveloped economies also means some negative effects, including: higher competition for domestic enterprises (some of them may go bankrupt), raw materials exploitation, possible political domination, worsening balance of payments in the long run (due to transfer of profits abroad), danger of indebtedness, dependence on imported technologies and products (Krugman, Obstfeld, 2003: 672; Siddiqui, 2014: 29-46).

There is no single superior theory which comprehensively explains international transfer of capital. A number of theoretical approaches can be found in the literature on the subject, as: macroeconomic theories (closely related to international economics and international trade perspective) and microeconomic ones (based on the theories of firm and industrial organization) (Kojima, 1984: 1-20; Nayak, Choudhury, 2014: 2-12). As far as international transfer of capital in the form of foreign direct investment is concerned, theoretical approach is based on three integrative theoretical concepts: the theory of the international capital market, the firm theory and the theory of international trade (Popovici, Călin, 2014: 4-24). The following theories of FDI should be mentioned here: location advantage theory (Vernon, 1966: 190-207), internalization advantage theory (Rugman, Varbeke, 2008), ownership advantage theory (Kindelberger, 1969: 14-16), as well as a complex, eclectic theory (OLI paradigm) proposed by J. H. Dunning (Dunning, 2000: 163-190). According to the eclectic approach in OLI paradigm, foreign direct investment results from a combination of ownership advantage, location advantage and internalization advantage (Dunning, 2001: 173-190; Dunning, 1980: 9-31).

\section{Foreign direct investment studies: literature review}

Many studies were dedicated to international capital flows, both in regard to theoretical perspective, and empirical evidence. The importance of international transfer of capital in the world economy was discussed- 
among others - by P. Siemiątkowski (2010) and M. Jaworek (2013). FDI as a specific form of international capital flows was studied by J. Wurgler, M. Baker and C. F. Foler (2004), M. Blomström and A. Kokko (2002), C. K. Fung, K. Urzúa and Z. Zhao (2016), as well as M. Neuhaus (2006). The relationship between FDI and technology transfer was presented by J. Stephan (2005). The significance of FDI inflow into transition economies was underlined by M. Du Pont (2000), D. Tang (2017), R. Mitrovic, A. Juric and M. Joksimovic (2017), while N. Smith (2017) analysed the need for FDI in developed economies. S. Chaudhuri and U. Mukhopadhyay (2014) studied theoretical aspects of FDI in developing countries. FDI in China, India, Ireland, Malaysia, Mexico and Sub-Saharan Africa was presented by Y. Wei and V. N. Balasubramanyam (2005). FDI in South Asian economies was studied by P. Sahoo, G. Nataraj and R. K. Dash (2014). A. Bodomo (2017) described the recent trends in FDI inflow into the African economies. Prospects for future tendencies in FDI in post-crisis period were studied by N. Hashai and R. Ramamurti (2011), as well as G. Zekos (2016). M. D. Simionescu (2017) investigated determinants of FDI in Bulgaria and Romania in post-crisis period. D. Collins (2013) focused on the evolution of outward FDI from BRIC economies. Outward FDI as exemplified by selected new EU Member States was analysed by M. Lindič (2017), A. V. Kuznetsov and A. A. Nevskaja (2017). Governmental attempts to promote outward FDI were described by J. Alcaraz and J. Zamilpa (2017).

\section{Investment attractiveness of the Visegrad 4 countries}

International transfer of capital in the form of foreign direct investment is considered to be one of the most dynamic phenomena in the world economy in the $21^{\text {st }}$ century. Thanks to FDI international economic integration is promoted and strengthened. A considerably high level of investment attractiveness is needed in order to attract capital in the form of FDI. Moreover, a favourable investment climate is vital for long term investment and business activity (Rymarczyk, Błaszczyk, Michalski, Niemiec, Niemiec, Wróblewski, 2008: 18; Kozłowska, 2015: 93-95).

The United Nations Economic Commission for Europe (UNECE) has defined a sound investment climate as "the conditions that make up the enabling environment in which private enterprises thrive by investing and producing", "conduciveness of private investment and enterprise growth" and "the state of enabling environment for private enterprise" (UNECE, 2004: 4-5). Investment climate results from:

- macroeconomic conditions (low inflation rate and responsible fiscal policy are highly rated by investors, while unpredictable and too loose monetary policy and fiscal policy do increase the risk);

- microeconomic and institutional framework (legal system and regulations promoting competition and improving access to financial resources are appreciated by investors),

- physical infrastructure (network of high quality roads, railways, telecommunication links is needed for investment activity) (UNECE, 2004: 4-5).

According to W. Karaszewski investment attractiveness is built by: demographic and geographical factors, socio-political factors (including political stability of an economy, entry rules and regulations for foreign capital, competition policy, tax regulations), economic factors (such as: market size and structure, consumers' preferences, income per capita, inflation rate, national economy's indebtedness, quantity and quality of labour, access to raw materials, technologies, expenditure on research and development activity, as well as factors relating to business environment (including favourable investment climate, investment stimuli, level of investment risk, social benefits, quality of administration, technical and financial infrastructure) (Karaszewski, 2004: 150).

As far as investors' decisions are concerned, investment attractiveness perceived by potential investors is of crucial importance. Therefore, the results of surveys presented by EY (earlier: Ernst\&Young) in the reports published each and every year seem of vital significance.

The Visegrad Group (V4) consisting of Poland, the Czech Republic, Slovakia and Hungary constitute a vital part of the Central and Eastern Europe region (CEE) (Ivanová, Masárová, 2018: 270-289; Molendows- 
ki, 2014: 1006-1013; Kořan, 2012: 201-210). One should stress here that Central and Eastern Europe has been listed among one of the most attractive regions in the world (see Table 1). In 2007,39\% of investors questioned by Ernst \& Young considered CEE as the $3^{\text {rd }}$ most attractive region in the world (after Western Europe and China and ahead of North America). In 2008, the CEE region took the $2^{\text {nd }}$ position after China and ahead of both Western Europe and North America (42\%). A year later, the CEE region was also perceived as the second most attractive region for investment location, just after Western Europe (39\%). The years 2010-2014 should be seen as the least advantageous period for the CEE region in terms of perceived investment attractiveness (less than $30 \%$ of questioned investors considered the CEE region as one of the most attractive regions in the world). The years 2016-2018 showed an upward tendency: in 2018 the CEE region was rated as the number three region in terms of investment attractiveness ( $41 \%$ of investors placed CEE among the most attractive regions in the world).

Table 1. Attractiveness by region, 2007-2017 (\% of answers)

\begin{tabular}{|l|l|l|l|l|l|l|l|l|l|l|l|}
\hline \multicolumn{1}{|c|}{ Specification } & $\mathbf{2 0 0 7}$ & $\mathbf{2 0 0 8}$ & $\mathbf{2 0 0 9}$ & $\mathbf{2 0 1 0}$ & $\mathbf{2 0 1 1}$ & $\mathbf{2 0 1 3}$ & $\mathbf{2 0 1 4}$ & $\mathbf{2 0 1 5}$ & $\mathbf{2 0 1 6}$ & $\mathbf{2 0 1 7}$ & $\mathbf{2 0 1 8}$ \\
\hline Western Europe & 55 & 33 & 40 & 38 & 33 & 37 & 45 & 50 & 53 & 53 & 53 \\
\hline Central and Eastern Europe & $\mathbf{3 9}$ & $\mathbf{4 2}$ & $\mathbf{3 9}$ & $\mathbf{2 4}$ & $\mathbf{2 1}$ & $\mathbf{2 8}$ & $\mathbf{2 9}$ & $\mathbf{2 8}$ & $\mathbf{3 7}$ & $\mathbf{3 7}$ & $\mathbf{4 1}$ \\
\hline Northern America & 38 & 21 & 33 & 22 & 21 & 28 & 31 & 39 & 39 & 39 & 34 \\
\hline China & 48 & 47 & 25 & 22 & 44 & 43 & 44 & 38 & 37 & 37 & 42 \\
\hline
\end{tabular}

Source: Ernst \& Young 2008; Ernst \& Young, 2009; Ernst \& Young, 2010; Ernst \& Young, 2011; Ernst \& Young, 2012; Ernst \& Young, 2013; EY, 2014; EY, 2015; EY, 2016; EY, 2017; EY, 2018.

Table 2. The Visegrad 4 in "Ease of doing business" ranking in 2008 (ranks)

\begin{tabular}{|l|l|l|l|l|l|l|l|l|l|l|l|}
\hline \multicolumn{1}{|c|}{ Economy } & \multicolumn{1}{|c|}{ Ease of doing business } & A & \multicolumn{1}{c|}{ B } & \multicolumn{1}{|c|}{ C } & \multicolumn{1}{|c|}{ D } & \multicolumn{1}{|c|}{ E } & \multicolumn{1}{|c|}{ G } & \multicolumn{1}{|c|}{ H } & \multicolumn{1}{|c|}{ I } & \multicolumn{1}{|c|}{ K } \\
\hline Poland & 74 & 129 & 156 & 78 & 81 & 68 & 33 & 125 & 40 & 68 & 88 \\
\hline Czech Republic & 56 & 91 & 83 & 55 & 54 & 26 & 83 & 113 & 30 & 97 & 108 \\
\hline Slovakia & 32 & 72 & 50 & 75 & 5 & 7 & 98 & 122 & 90 & 50 & 36 \\
\hline Hungary & 45 & 67 & 87 & 81 & 96 & 26 & 107 & 127 & 45 & 12 & 53 \\
\hline
\end{tabular}

Legend: A - Starting a business; B - Dealing with construction permits; C - Getting electricity; D - Registering property; E - Getting credit; F - Protecting minority investors; G - Paying taxes; H - Trading across borders; I - Enforcing contracts; K - Resolving insolvency. (Total: 178 economies).

Source: Doing Business 2008 (2008).

The International Bank for Reconstruction and Development / The World Bank Group evaluates national economies in regard to the environment for doing business. The position of a national economy in "Ease of doing business" ranking results from its place in 10 areas: Starting a business; Dealing with construction permits (earlier: Dealing with licenses); Getting electricity (earlier: Employing workers); Registering property; Getting credit; Protecting minority investors (earlier: protecting investors); Paying taxes; Trading across borders; Enforcing contracts; Resolving insolvency (earlier: Closing a business) (Ernst \& Young, 2008; Ernst \& Young, 2013; EY, 2018). Each of the above listed areas is assessed by a number of elements. Procedures, costs and time are most often used for the evaluation. For example, dealing with construction permits is assessed by: a number of procedures, time for their implementation and costs connected with the process of construction permit granting (as \% of income per capita). Tables 2, 3 and 4 present the Visegrad 4 countries in "Ease of doing business" rankings in 2008, 2013 and 2018.

In 2008, the highest position in the "Ease of doing business' ranking" of all V4 countries was taken by Slovakia $\left(32^{\text {nd }}\right)$, while Poland was placed on the $74^{\text {th }}$ place (in total the ranking included 178 economies in 
2008). Slovakia's relatively high position resulted from its $5^{\text {th }}$ place in terms of 'Registering property' and its $7^{\text {th }}$ position regarding 'Getting credit'. It could have been even higher if not for a relatively low result in terms of 'Paying taxes' $\left(122^{\text {nd }}\right.$ place $)$. Poland's poor condition resulted from: the $129^{\text {th }}$ position in regard to 'Starting a business', the $156^{\text {th }}$ position in terms of 'Dealing with licenses' and the $125^{\text {th }}$ place regarding 'Paying taxes'.

Between 2008 and 2018, the overall picture of the V4 in the "Ease of doing business" rankings changed significantly for the better. In 2013, Poland was classified on the $45^{\text {th }}$ position and it was the highest position among the V4 (in total the ranking included 185 economies). Slovakia took the $49^{\text {th }}$ place, Hungary was positioned in the $54^{\text {th }}$ place, while the Czech Republic took the lowest place among the V4 - the $75^{\text {th }}$ one. As far as Poland's relatively high position is concerned, one should note its $3^{\text {rd }}$ place in terms of 'Getting credit'. On the other hand, however, Poland's $137^{\text {th }}$ place in regard to 'Getting electricity', as well as its $116^{\text {th }}$ place regarding 'Starting a business' and its $113^{\text {th }}$ place in terms of Paying taxes should be viewed as crucial weaknesses of the Polish economy.

In 2018, the V4 countries were classified much higher in the "Ease of doing business" ranking. In total, the ranking revealed by E\&Y included 190 economies. The V4 took the following positions: Poland - the $27^{\text {th }}$ place, the Czech Republic - the $30^{\text {th }}$, Slovakia - the $39^{\text {th }}$ and finally Hungary - the $48^{\text {th }}$. All the V4 economies took the $1^{\text {st }}$ position in regard to 'Trading across borders'. Poland's position could have been even better if not for the $120^{\text {th }}$ place in terms of 'Starting a business', for in regard to other elements Poland's position ranged from the $22^{\text {nd }}$ to the $55^{\text {th }}$. In the case of the Czech Republic, one should note a relatively low position in regard to 'Dealing with construction permits' (the $127^{\text {th }}$ place), while in the case of Hungary very low positions regarding both 'Getting electricity' (the $110^{\text {th }}$ place) and 'Protecting minority investors' (the $108^{\text {th }}$ position) must be underlined.

Table 3. The Visegrad 4 in "Ease of doing business" ranking in 2013 (ranks)

\begin{tabular}{|l|l|r|r|r|r|r|r|r|r|r|r|}
\hline \multicolumn{1}{|c|}{ Economy } & \multicolumn{1}{|c|}{ Ease of doing business } & A & B & C & D & E & F & \multicolumn{1}{c|}{ G } & H & I & K \\
\hline Poland & 45 & 116 & 88 & 137 & 54 & 3 & 52 & 113 & 49 & 55 & 45 \\
\hline Czech Republic & 75 & 146 & 86 & 146 & 37 & 55 & 98 & 122 & 68 & 75 & 75 \\
\hline Slovakia & 49 & 108 & 53 & 65 & 11 & 42 & 115 & 102 & 108 & 65 & 49 \\
\hline Hungary & 54 & 59 & 47 & 112 & 45 & 55 & 128 & 124 & 70 & 15 & 70 \\
\hline
\end{tabular}

Legend: A - starting a business; B - Dealing with construction permits; C - Getting electricity; D - Registering property; $\mathrm{E}$ - Getting credit; F - Protecting minority investors; $\mathrm{G}$ - Paying taxes; $\mathrm{H}$ - Trading across borders; I - Enforcing contracts; K - Resolving insolvency. (Total: 185 economies).

Source: Doing Business 2013. Smarter Regulations for Small and Medium-Size Enterprises (2013).

Table 4. The Visegrad 4 in "Ease of doing business" ranking in 2018 (ranks)

\begin{tabular}{|l|l|l|l|l|l|l|l|l|l|l|l|}
\hline \multicolumn{1}{|c|}{ Economy } & \multicolumn{1}{|c|}{ Ease of doing business } & A & \multicolumn{1}{c|}{ B } & \multicolumn{1}{c|}{ C } & \multicolumn{1}{c|}{ D } & \multicolumn{1}{|c|}{ E } & \multicolumn{1}{|c|}{ F } & \multicolumn{1}{|c|}{ G } & H & I & K \\
\hline Poland & 27 & 120 & 41 & 54 & 38 & 29 & 51 & 51 & 1 & 55 & 22 \\
\hline Czech Republic & 30 & 81 & 127 & 15 & 32 & 42 & 62 & 53 & 1 & 91 & 25 \\
\hline Slovakia & 39 & 83 & 91 & 57 & 7 & 55 & 89 & 49 & 1 & 82 & 42 \\
\hline Hungary & 48 & 79 & 90 & 110 & 29 & 29 & 108 & 93 & 1 & 13 & 62 \\
\hline
\end{tabular}

Legend: A - starting a business; B - Dealing with construction permits; C - Getting electricity; D - Registering property; E - Getting credit; F - Protecting minority investors; G - Paying taxes; $\mathrm{H}$ - Trading across borders; I - Enforcing contracts; K - Resolving insolvency. (Total: 190 economies).

Source: Doing Business 2018. Reforming to Create Jobs (2018). 
The above analysis let me conclude that the V4 countries should not be viewed as a homogenous group. There are still considerable differences among them. What is common for them all, is their location in the central part of Europe, relatively cheap labour force (as compared to the West European economies - members of the European Union) and participation in the European Union, i.e., single market advantages and the Schengen area membership. In 1990s, all the V4 countries aspired to become members of the European Union and did perceive full membership in the EU as an important step forward in the process of their opening as well as in the process of overcoming artificial divisions which existed in Europe after the World War II (Visegrad Group, 2018; Czech, Pawlas, 2015: 89-91). Even here, however, one should note an important difference between Slovakia and other V4 countries: Slovakia introduced euro in 2009 and has been a member of euro zone since then, while three remaining V4 countries are still outside the euro zone. Undoubtedly this element constitutes a significant difference in regard to business activity and is taken into consideration by potential investors.

\section{The Visegrad 4 as a location of capital in the form of foreign direct investment}

It is believed that the inflow of capital in the form of foreign direct investment (FDI) stimulates economic development (Koizumi, Kopecky, 1977: 45-65). FDI creates stable and long-lasting relations and links between economies. FDI is a way of promoting the transfer of technology and 'know-how' between national economies (Tülüce, Doğan, 2014: 107-115). Import of FDI becomes especially significant in regard to so called catching up economies, due to extra funding sources for investment it offers. Moreover, the Visegrad 4 countries are perceived as such catching up economies. FDI inflows into the Visegrad 4 countries from 2007 to 2017 are presented in Table 5 to observe and examine whether the global financial crisis and later economic instability caused changes in the scale and dynamics of FDI inflows into the studied V4 economies.

As it stems from the presented data, in 2007, FDI inflows into the V4 countries amounted to almost USD 42 billion (it represented $4.86 \%$ of the total FDI inflows into the European Union). Unfortunately, the years $2008-$ 2018 brought a significant reduction in the FDI inflows into the analysed group of economies: the average amount of FDI inflows into the V4 in this period equalled USD 21.06 billion only (with the maximum of USD 32.72 billion observed in 2011 and the minimum of USD 1.09 billion noted in 2015). At the same time the average FDI inflows into the European Union amounted to USD 421.34 billion (which means the share of the V4 in the FDI inflow into the EU increased to some $4.99 \%$ on average), though in 2015 a significant reduction of the V4 share was observed: FDI inflows into the V4 represented only $0.18 \%$ of FDI inflows into the EU then). The analysis of FDI inflows into the individual V4 economies made it possible to conclude that Poland remained the biggest recipient of the capital in the form of FDI among the V4 from 2007 to 2017. In 2007, FDI inflows into Poland amounted to USD 23.56 billion and in the remaining years they ranged from USD 6.06 billion in 2012 to USD 20.62 billion in 2011; moreover, in 2013, one could observe divestment amounting to USD 6.04 billion (FDI inflows into Poland from 2008 to 2017 equalled USD 11.29 billion on average). Since 2015, a considerable worsening of the situation regarding FDI inflows into Hungary was observed: in both 2015 and 2016 divestments amounting to USD 14.75 billion and USD 5.85 billion were seen.

Table 5. FDI inflows into the Visegrad 4 and the EU from 2007 to 2017 (billion USD)

\begin{tabular}{|l|l|l|l|l|l|l|l|l|l|l|l|}
\hline \multicolumn{1}{|c|}{ Economy } & \multicolumn{1}{|c|}{$\mathbf{2 0 0 7}$} & $\mathbf{2 0 0 8}$ & $\mathbf{2 0 0 9}$ & $\mathbf{2 0 1 0}$ & $\mathbf{2 0 1 1}$ & $\mathbf{2 0 1 2}$ & $\mathbf{2 0 1 3}$ & $\mathbf{2 0 1 4}$ & $\mathbf{2 0 1 5}$ & $\mathbf{2 0 1 6}$ & $\mathbf{2 0 1 7}$ \\
\hline Poland & 23.56 & 14.84 & 13.70 & 13.88 & 20.62 & 6.06 & -6.04 & 14.27 & 15.27 & 13.93 & 6.43 \\
\hline Czech Republic & 10.44 & 6.45 & 2.93 & 6.14 & 2.32 & 7.98 & 4.99 & 5.49 & 0.46 & 9.81 & 7.41 \\
\hline Slovakia & 4.02 & 4.69 & -0.05 & 1.77 & 3.49 & 2.83 & 0.59 & -0.51 & 0.11 & -0.29 & 2.28 \\
\hline Hungary & 3.95 & 6.16 & 7.38 & 2.20 & 6.29 & 13.98 & 3.09 & 7.81 & -14.75 & -5.85 & 2.49 \\
\hline Visegrad 4 & 41.97 & 32.14 & 23.96 & 23.99 & 32.72 & 30.85 & 2.63 & 27.06 & 1.09 & 17.60 & 18.60 \\
\hline European Union & 864.04 & 487.97 & 346.53 & 383.70 & 490.43 & 216.01 & 246.21 & 274.55 & 595.16 & 564.94 & 333.72 \\
\hline
\end{tabular}

Source: UNCTAD, 2011; UNCTAD, 2014; UNCTAD, 2018. 
Table 6 presents inward FDI stock in the Visegrad 4 countries and in the EU from 2007 to 2017. Inward FDI stock in the V4 amounted to USD 434.0 billion in 2007, which stood for $5.72 \%$ of the total inward FDI stock in the European Union. Yet $41.11 \%$ of the total inward FDI stock in the V4 in 2007 was represented by the inward FDI stock in Poland (which amounted to USD 178.41 billion then). From 2007 to 2017 inward FDI stock in the V4 increased up to USD 533.27 billion, while the total inward FDI stock in the European Union rose to USD 9133.98 billion; therefore, the share of the V4 in inward FDI stock in the EU slightly increased during the analysed period of time up to 5.84\% in 2017. In 2017, inward FDI stock in Poland amounted to USD $234.44 \%$, which represented $43.96 \%$ of the total FDI stock in the V4 and $43.96 \%$ of the total inward FDI in the V4.

Table 6. Inward FDI stock in the Visegrad 4 and the EU from 2007 to 2017 (billion USD)

\begin{tabular}{|l|c|c|c|c|c|c|c|c|c|c|c|}
\hline Economy & $\mathbf{2 0 0 7}$ & $\mathbf{2 0 0 8}$ & $\mathbf{2 0 0 9}$ & $\mathbf{2 0 1 0}$ & $\mathbf{2 0 1 1}$ & $\mathbf{2 0 1 2}$ & $\mathbf{2 0 1 3}$ & $\mathbf{2 0 1 4}$ & $\mathbf{2 0 1 5}$ & $\mathbf{2 0 1 6}$ & $\mathbf{2 0 1 7}$ \\
\hline Poland & 178.41 & 164.31 & 186.11 & 215.64 & 203.11 & 235.11 & 252.04 & 211.48 & 185.99 & 186.31 & 234.44 \\
\hline $\begin{array}{l}\text { Czech } \\
\text { Republic }\end{array}$ & 112.41 & 113.17 & 125.83 & 128.50 & 120.57 & 136.44 & 135.98 & 121.51 & 116.63 & 121.85 & 153.47 \\
\hline Slovakia & 47.71 & 51.03 & 52.64 & 50.33 & 51.98 & 55.82 & 58.83 & 49.74 & 46.01 & 43.74 & 52.03 \\
\hline Hungary & 95.47 & 88.53 & 98.76 & 90.77 & 85.43 & 103.48 & 111.01 & 99.57 & 84.82 & 80.55 & 93.33 \\
\hline Visegrad4 & 434.00 & 417.04 & 463.34 & 485.24 & 461.09 & 530.85 & 557.86 & 482.30 & 433.45 & 432.45 & 533.27 \\
\hline $\begin{array}{l}\text { European } \\
\text { Union }\end{array}$ & 7589.15 & 6490.77 & 7296.07 & 7313.82 & 7481.55 & 8019.94 & 8582.67 & 7936.56 & 7933.00 & 8028.10 & 9123.98 \\
\hline
\end{tabular}

Source: UNCTAD, 2011; UNCTAD, 2014; UNCTAD, 2018.

In 2017, inward FDI stock in Poland accounted for 48.5\% GDP, while in the Czech Republic it exceeded $78 \%$ GDP, in Slovakia it accounted for over 58\% GDP and in Hungary it equalled 74.5\% GDP. At the same time inward FDI stock in the European Union reached 56.5\% GDP.

Table 7 presents the Visegrad 4 countries on the list of TOP 20 destinations by FDI projects and by FDI job creation in 2015, 2016 and 2017.

Table 7. The Visegrad 4 countries on the list of TOP 20 destination countries by FDI projects and by FDI job creation in 2015-2017

\begin{tabular}{|c|c|c|c|c|c|c|c|c|c|c|c|c|}
\hline \multirow[b]{2}{*}{ Country } & \multicolumn{2}{|c|}{2015} & \multicolumn{2}{|c|}{2016} & \multicolumn{2}{|c|}{2017} & \multicolumn{2}{|c|}{2015} & \multicolumn{2}{|c|}{2016} & \multicolumn{2}{|c|}{2017} \\
\hline & $\begin{array}{c}\text { Posi- } \\
\text { tion }\end{array}$ & $\begin{array}{c}\text { Number } \\
\text { of FDI } \\
\text { projects }\end{array}$ & $\begin{array}{l}\text { Posi- } \\
\text { tion }\end{array}$ & $\begin{array}{c}\text { Number } \\
\text { of FDI } \\
\text { projects }\end{array}$ & $\begin{array}{l}\text { Posi- } \\
\text { tion }\end{array}$ & $\begin{array}{c}\text { Number } \\
\text { of FDI } \\
\text { projects }\end{array}$ & $\begin{array}{c}\text { Posi- } \\
\text { tion }\end{array}$ & $\begin{array}{c}\text { Number } \\
\text { of jobs } \\
\text { created } \\
\text { by FDI }\end{array}$ & $\begin{array}{c}\text { Posi- } \\
\text { tion }\end{array}$ & $\begin{array}{l}\text { Num- } \\
\text { ber of } \\
\text { jobs } \\
\text { created } \\
\text { by FDI }\end{array}$ & $\begin{array}{c}\text { Posi- } \\
\text { tion }\end{array}$ & $\begin{array}{c}\text { Num- } \\
\text { ber of } \\
\text { jobs } \\
\text { creat- } \\
\text { ed by } \\
\text { FDI }\end{array}$ \\
\hline Poland & 5 & 211 & 5 & 256 & 9 & 197 & 2 & 19651 & 2 & 22074 & 5 & 24000 \\
\hline $\begin{array}{l}\text { Czech } \\
\text { Republic }\end{array}$ & 15 & 70 & 13 & 110 & 12 & 134 & 10 & 9332 & 8 & 14292 & 8 & 14490 \\
\hline Slovakia & 18 & 54 & 19 & 70 & - & - & 9 & 9564 & 12 & 8308 & - & - \\
\hline Hungary & 13 & 94 & 14 & 107 & 15 & 116 & 7 & 11741 & 10 & 12450 & 7 & 17017 \\
\hline
\end{tabular}

Source: EY, 2016; EY, 2017; EY, 2018.

Poland took the $5^{\text {th }}$ position on the list of TOP 20 destination countries by FDI projects both in 2015 and 2016. In 2015, 211 FDI projects were realized in Poland, while in 2016 the number of FDI projects realized on the territory of Poland reached 256. Other V4 countries could be found in the second ten. In 2015, Hungary occupied the $13^{\text {th }}$ position with 94 FDI projects, the Czech Republic was classified as the 
$15^{\text {th }}$ economy with 70 FDI projects, while Slovakia was positioned on the $18^{\text {th }}$ place with 54 FDI projects. In 2016, the Czech Republic took the $13^{\text {th }}$ position with 110 FDI projects, Hungary was placed on the $14^{\text {th }}$ place with 107 FDI projects and Slovakia was classified as the $19^{\text {th }}$ economy in terms of the number of FDI projects (70 FDI projects were realized in Slovakia then). As far as FDI job creation is concerned, the positions of the V4 countries are even higher. Poland took the $2^{\text {nd }}$ place in both 2015 and 2015 with over 19650 FDI jobs created in 2015 and over 22070 FDI jobs created in 2016. Other V4 countries were also classified in the TOP 10 destination countries by FDI job creation in 2015, taking places: $7^{\text {th }}$ (Hungary), $9^{\text {th }}$ (Slovakia) and $10^{\text {th }}$ (Czech Republic). In 2016, the Czech Republic improved its position and was classified as the $8^{\text {th }}$ destination economy in terms of FDI job creation (with almost 14300 FDI jobs created), while the positions of both Hungary and Slovakia slightly worsened (they took the $10^{\text {th }}$ position and the $12^{\text {th }}$ place respectively). In 2017, the situation changed significantly as far as the V4 picture is concerned: Poland lost its $2^{\text {nd }}$ position, it was positioned on the $9^{\text {th }}$ place both in regard to the number of FDI projects (197) and on the $5^{\text {th }}$ place in terms of the number of jobs created by FDI (though this number increased up to 24000). The Czech Republic improved its position in terms of the number of FDI projects ( $10^{\text {th }}$ place with 134 FDI projects) and in regard to the number of jobs created by FDI (almost 15000). Hungary was classified as the $15^{\text {th }}$ economy in terms of the number of FDI projects (116) and as the $7^{\text {th }}$ one in terms of the number of jobs created by FDI (over 17000). Slovakia was not included on the list.

\section{The Visegrad 4 countries as investors in the world market}

Due to the rising intensity of globalization processes and the increasing openness of national economies, even countries characterized by a medium level of economic development do participate in the international transfer of capital as exporters of FDI. Outward FDI flows from the Visegrad 4 countries and from the EU from 2007 to 2017 are presented in Table 8. Undoubtedly, the V4 countries should not be perceived as important players in regard to outward FDI - though they also invest internationally (mostly in Europe). They do remain net importers of capital in the form of FDI. Their role as exporters of capital in the form of FDI is very limited. In 2007, total outward FDI flows from the V4 countries amounted to USD 11.33 billion (USD 5.40 billion invested by Poland in the world market in the form of FDI, which constituted $47.66 \%$ of total outward FDI flows from the V4). In 2007, outward FDI flows from the V4 represented only $0.9 \%$ of total outward FDI flows from the European Union (which amounted to USD 1257.67 billion in this very year). The average outward FDI flows from the V4 countries from 2008 to 2017 amounted to USD 6.67 billion (in that outward FDI flows from Poland amounting to USD 4.02 billion), while the average for the European Union equalled USD 455.03 billion. The highest level of outward FDI flows from the V4 was noted in 2011-2012 (over USD 13 billion in both years). On the other hand, the worst situation in regard to the V4 outward FDI flows was observed in 2015 with divestment amounting to almost USD 9 billion.

Table 8. Outward FDI flows from the Visegrad 4 and the EU from 2007 to 2017 (billion USD)

\begin{tabular}{|l|l|l|l|l|l|l|l|l|l|l|l|}
\hline Economy & \multicolumn{1}{|c|}{$\mathbf{2 0 0 7}$} & $\mathbf{2 0 0 8}$ & $\mathbf{2 0 0 9}$ & $\mathbf{2 0 1 0}$ & $\mathbf{2 0 1 1}$ & $\mathbf{2 0 1 2}$ & $\mathbf{2 0 1 3}$ & $\mathbf{2 0 1 4}$ & $\mathbf{2 0 1 5}$ & $\mathbf{2 0 1 6}$ & $\mathbf{2 0 1 7}$ \\
\hline Poland & 5.40 & 4.14 & 5.20 & 7.23 & 8.16 & 0.73 & -4.85 & 2.90 & 4.99 & 8.07 & 3.59 \\
\hline $\begin{array}{l}\text { Czech } \\
\text { Republic }\end{array}$ & 1.62 & 4.32 & 0.95 & 1.17 & -0.33 & 1.79 & 3.29 & 1.62 & 2.49 & 2.18 & 1.62 \\
\hline Slovakia & 0.67 & 0.53 & 0.43 & 0.95 & 0.71 & -0.07 & -0.42 & 0.04 & 0.01 & 0.25 & 0.35 \\
\hline Hungary & 3.62 & 3.11 & 2.70 & 1.15 & 4.66 & 11.34 & 2.27 & 3.87 & -16.19 & -8.55 & 0.32 \\
\hline Visegrad 4 & 11.33 & 12.10 & 9.28 & 10.50 & 13.20 & 13.79 & 0.29 & 8.43 & -8.7 & 1.95 & 5.88 \\
\hline $\begin{array}{l}\text { European } \\
\text { Union }\end{array}$ & 1257.67 & 906.20 & 370.02 & 483.00 & 585.27 & 237.86 & 250.46 & 222.24 & 606.65 & 452.87 & 435.74 \\
\hline
\end{tabular}

Source: UNCTAD, 2011; UNCTAD, 2014; UNCTAD, 2018. 
Table 9 presents outward FDI stock from the Visegrad 4 countries and from the EU from 2007 to 2017. In 2007, outward FDI stock from the V4 reached USD 49.28 billion (including USD 21.32 billion outward FDI stock from Poland), while outward FDI stock from the European Union was close to USD 8742.3 billion.

Table 9. Outward FDI stock from the Visegrad 4 and the EU from 2007 to 2017 (billion USD)

\begin{tabular}{|c|c|c|c|c|c|c|c|c|c|c|c|}
\hline Economy & 2007 & 2008 & 2009 & 2010 & 2011 & 2012 & 2013 & 2014 & 2015 & 2016 & 2017 \\
\hline Poland & 21.32 & 24.03 & 29.61 & 44.44 & 52.85 & 57.37 & 54.97 & 27.76 & 27.49 & 29.29 & 30.98 \\
\hline $\begin{array}{l}\text { Czech } \\
\text { Republic }\end{array}$ & 8.56 & 12.53 & 14.80 & 14.92 & 13.21 & 15.18 & 21.38 & 18.23 & 18.59 & 19.43 & 23.65 \\
\hline Slovakia & 2.08 & 2.98 & 3.70 & 3.46 & 4.02 & 4.41 & 4.29 & 2.82 & 2.46 & 2.65 & 3.41 \\
\hline Hungary & 17.32 & 20.08 & 22.49 & 20.43 & 24.35 & 35.06 & 39.61 & 40.66 & 35.32 & 24.42 & 28.61 \\
\hline Visegrad4 & 49.28 & 59.62 & 70.60 & 83.25 & 94.43 & 112.02 & 120.25 & 89.47 & 83.86 & 75.79 & 86.65 \\
\hline $\begin{array}{l}\text { European } \\
\text { Union }\end{array}$ & 8742.29 & 7914.63 & 9083.52 & 9315.06 & 9517.55 & 9830.35 & 10616.76 & 9161.15 & 9377.76 & 9458.99 & 10631.71 \\
\hline
\end{tabular}

Source: UNCTAD, 2011; UNCTAD, 2014; UNCTAD, 2018.

That means that outward FDI stock from the V4 represented only $0.56 \%$ of outward FDI stock from the European Union. In the analysed period of time, outward FDI stock from the EU increased so as to reach USD 10631.71 billion in 2017, while outward FDI stock from the V4 in 2017 amounted to USD 86.65 billion (including USD 30.98 billion, i.e., $35.75 \%$ from Poland), which stood for $0.82 \%$ of total outward FDI stock from the EU. In 2017, outward FDI stock from Poland reached 6.4\% GDP, while for the Czech Republic it was a bit over to $12 \%$ GDP and in the case of Slovakia it accounted for only $3.8 \%$ GDP while for Hungary it equalled 22.8\% GDP. At the same time outward FDI stock from the European Union accounted for almost $66 \%$ GDP.

\section{Conclusions}

Political and economic transition of the Visegrad 4 countries and their economies' opening in the last decade of the $20^{\text {th }}$ century resulted in the creation of favourable conditions for the inflow of foreign capital in the form of direct investment. Full access of the Visegrad 4 countries to the European Union constituted another impulse for strengthening the investment attractiveness of those Central European economies in the eyes of foreign investors (Allen \& Owery, 2011: 4-7). Their participation in regional economic integration processes within the European Union, i.e., the advantages resulting from four freedoms of the Single European Market and the implementation of EU Policy of Economic, Social and Territorial Cohesion, and in particular the benefits from the Cohesion Fund and structural funds (mostly European Regional Development Fund and - to some extent - the European Social Fund) resulted in a much higher perceived investment attractiveness of the analysed economies. Other trumps of the V4 economies as a location for FDI included: relatively cheap and still well-educated labour, high dynamics of IT market, rising internal demand due to emerging market growth. Among the barriers for FDI in the V4 economies one could find: shortages of infrastructure, high taxes, bureaucracy, low R\&D expenditures, low innovativeness. Moreover, global financial crisis $2008+$ followed later by economic instability in the region resulted in some negative phenomena regarding FDI in the analysed group of countries.

Poland was - and still is - the biggest recipient of FDI among the Visegrad 4 countries. In the studies period of time inward FDI stock in Poland increased by over 31\% and reached USD 234.44 billion in 2017 (in 2007 it amounted to USD 178.41 billion). One should note here that in regard to per capita inward FDI stock Poland occupied the very last position among the Visegrad 4 countries (in 2017 inward FDI stock in Poland amounted to USD 6170 per capita, while in Hungary it was over 9400, in Slovakia it was about USD 9600 and in the case of the Czech Republic it equalled USD 14600). 
The analysis of engagement of the V4 in international transfer of capital in the form of FDI leads to a general conclusion that foreign capital played an important role in the transformation of the V4 economies, increasing their integration with the globalized world economy. It contributed to supplementing capital shortages and increasing efficiency. The Visegrad 4 countries remain net importers of capital in the form of FDI. Moreover, due to comparatively cheap labour in Poland, Hungary, the Czech Republic and Slovakia, the V4 countries are chosen as FDI location by investors creating relatively high numbers of jobs.

It should be underlined, however, that the positions of the V4 as investors in the world market have risen slightly over the last decade. Outward FDI stock of the Visegrad 4 countries increased from a bit over USD 49 billion in 2007 to almost USD 87 billion in 2007. In Poland, one could observe an increase by almost 50\% (from a bit over USD 21 billion in 2007 to almost USD 31 billion in 2017). Outward FDI stock from the Czech Republic almost trebled between 2007 and 2017 (it increased from USD 8.56 billion to USD 23.56 billion). Yet Hungarian outward FDI stock in the world increased from USD 17.3 billion in 2007 to USD 28.6 billion in 2017 (the rise would have been much more significant if not for a downward tendency observed in the 2015-2016 period). Nevertheless, the scale of inward FDI stock in the Visegrad 4 countries is several times higher than their capital investment in the world markets. One should, therefore, suggest undertaking actions aiming at strengthening the engagement of the Visegrad 4 countries in the export of FDI both in Europe (mostly the European Union single market) and worldwide.

It is of vital importance to introduce dynamic and effective actions aiming at promoting the V4 as a location of FDI and to undertake parallel activities directed at stimulating the V4 investment abroad. Increased attractiveness could result in higher FDI inflow into the V4, while increased aggressiveness should bring more intense export of capital in the form of FDI from the V4. The combined stronger inward and outward FDI activity would result in higher competitiveness of the V4.

Limitations of the research include the lack of geographical pattern and branch structure of FDI in the analysis. Unfortunately, those elements could not be taken into consideration in this work due to a limited size and capacity of the article. The above-mentioned limitations point to the need for further (more detailed) research in the area of the Visegrad 4 countries' engagement in international transfer of capital in the form of FDI.

\section{References}

Alcaraz, J., Zamilpa, J. (2017). Latin American Governments in the Promotion of Outward FDI. Transnational Corporations, Vol. 24, No. 2, p. 91-108.

Allen \& Overy. (2011). CEE You There. Foreign Direct Investment in Central and Eastern Europe.

Blomström, M., Kokko, A. (2002). FDI and Human Capital: A Research Agenda. Paris: OECD.

Bodomo, A. (2017). The Globalization of Foreign Investment in Africa: The Role of Europe, China and India. Bingley: Emerald Group Publishing Limited.

Chaudhuri, S., Mukhopadhyay, U. (2014). Foreign Direct Investment in Developing Countries: A Theoretical Evaluation. New Delhi: Springer.

Collins, D. (2013). The BRIC States and Outward Foreign Direct Investment. Oxford: Oxford University Press.

Czech, K., Pawlas, I. (2015). Nowe kraje Unii Europejskiej jako uczestnicy międzynarodowego transferu kapitału w warunkach integracji europejskiej. Studia Ekonomiczne. Zeszyty Naukowe Uniwersytetu Ekonomicznego w Katowicach, No. 218, p. 88-98.

Doing Business 2018. Reforming to Create Jobs. (2018). Washington: International Bank for Reconstruction and Development / The World Bank.

Doing Business 2013. Smarter Regulations for Small and Medium-Size Enterprises. (2013). Washington: International Bank for Reconstruction and Development / The World Bank.

Doing Business 2008. (2008). Washington: The International Bank for Reconstruction and Development / The World Bank.

Dunning, J. H. (2001). The Eclectic (OLI) Paradigm of International Production: Past, Present and Future. International Journal of the Economics and Business, Vol. 8, Issue 2, p. 173-190.

Dunning, J. H. (2000). The Eclectic Paradigm as an Envelope for Economic and Business Theories of MNE Activity. International Business Review, Issue 9(1), p. 163-190.

Dunning, J. H. (1980). Toward an Eclectic Theory of International Production: Some Empirical Tests. Journal of International Business Studies, Vol. 11, No. 1 (Spring-Summer), p. 9-31. 
Du Pont, M. (2000). Foreign Direct Investment in Transitional Economies: A Case Study of China and Poland. New York: St. Martin's Press.

Ernst \& Young. (2013). Ernst \& Young's Attractiveness Survey. Europe 2013. Coping with the Crisis. The European Way.

Ernst \& Young. (2012). Ernst \& Young's European Attractiveness Survey 2012. Growth, Actually.

Ernst \& Young. (2011). Ernst \& Young's 2011 European Attractiveness Survey. Restart.

Ernst \& Young. (2010). Ernst \& Young's 2010 European Attractiveness Survey. Waking up to the New Economy.

Ernst \& Young. (2009). Ernst \& Young's 2009 European Attractiveness Survey. Reinventing European Growth.

Ernst \& Young. (2008). Ernst \& Young's 2008 European Attractiveness Survey. An Open world.

Ernst \& Young. (2018). EY's Attractiveness Survey Europe 2018. Game Changers.

Ernst \& Young. (2017). EY's Attractiveness Survey Europe 2017. Investors Vote: Remain in Europe.

Ernst \& Young. (2016). EY's Attractiveness Survey Europe 2016. How can Europe's Investors Turn Resilience into Growth?

Ernst \& Young. (2015). EY's Attractiveness Survey Europe 2015. Comeback Time.

Ernst \& Young. (2014). EY's Attractiveness Survey. Europe 2014. Back in the Game.

Feldstein, M., Horioka, C. (1980). Domestic Saving and International Capital Flows. Economic Journal, No. 90 (358), p. 314-329.

Fung, C. K., Urzúa, K., Zhao, Z. (2016). Two-Way Trade Flows and FDI between China and Latin America. Bradford: West Yorkshire Emerald Group Publishing Limited.

Hashai, N., Ramamurti, R. (2011). The Future of Foreign Direct Investment and the Multinational Enterprise. Bingley: Emerald Group Pub. Ltd.

IMF (2016). IMF Executive Board Discusses Review of Experience with the Institutional View on the Liberalization and Management of Capital Flows. Washington: IMF. Press Release No. 16/573, p. 1-4.

Ivanová, E., Masárová, J. (2018). Performance Evaluation of the Visegrad Group Countries. Economic ResearchEkonomska Istraživanja, Vol. 31, Issue 1, p. 270-289.

Jaworek, M. (2013). Ocena ekonomicznej efektywności bezpośrednich inwestycji zagranicznych w praktyce polskich przedsiębiorstw. Toruń: Wydawnictwo Naukowe Uniwersytetu Mikołaja Kopernika, 314 p.

Karaszewski, W. (2004). Bezpośrednie inwestycje zagraniczne - Polska na tle świata, Toruń: Towarzystwo Naukowe Organizacji i Kierownictwa.

Kindelberger, C. P. (1969). American Business Abroad. New Haven: Yale University Press.

Klave, A. J., Makać, A. (1987). Zarys międzynarodowych stosunków ekonomicznych. Warszawa: PWE, p. $213-216$.

Koizumi, T., Kopecky, K. J. (1977). Economic Growth, Capital Movements and the International Transfer of Technical Knowledge. Journal of International Economics, Vol. 7, Issue 1, February, p. 45-65.

Kojima, K. (1984). Micro and Macro Economic Models of Foreign Direct Investment: Towards a Synthesis. Hitotsubachi Journal of Economics, No. 25 (2), p. 1-20.

Kořan, M. (2012). The Visegrad Group on the Threshold of Its Third Decade: A Central European Hub? In Z. Šabič, P. Drulák (eds.). Regional and International Relations of Central Europe. London: Palgrave Macmillan, p. $201-210$.

Kozłowska, M. (2015). Problems Connected with Measuring Risks of Foreign Direct Investments. Journal of Economics and Management, Vol. 20, p. 93-105.

Krugman, P. R., Obstefld, M. (2003). International Economics. Theory and Policy. $6^{\text {th }}$ edition. Boston-San FranciscoNew York-London: Addison Wesley.

Kuznetsov, A. V., Nevskaâ, A. A. (2017). Geography of FDI from Visegrad Countries in Russia. Bulletin of Geography. Socio-Economic Series, No. 36, p. 107-115.

Lindič, M. (2017). The Effects of Outsourcing and Outward FDI on Skill Structure in Slovenia: Evidence on Matched Firm-Employee Data. Economic and Business Review, Vol. 19, Issue 3, p. 365-413.

Mitrovic, R., Juric, A., Joksimovic, M. (2017). Impact of FDI on the Economic Development of Serbia and Poland. Progress in Economic Sciences, No. 4, p. 404-414.

Molendowski, E. (2014). The Visegrad Group Countries - Changes in Intra-Industry Competitiveness of their Economies during the World Financial and Economic Crisis. Procedia - Social and Behavioral Sciences, Vol. 110, January, p. 1006-1113.

Nayak, D., Choudhury, R. N. (2014). A Selective Review of Foreign Direct Investment Theories. ARTNeT Working Paper Series, No. 143, Asia-Pacific Research and Training Network on Trade (ARTNeT), Bangkok, p. 2-12.

Neuhaus, M. (2006). Impact of FDI on Economic Growth: An Analysis for the Transition Countries of Central and Eastern Europe. Heidelberg: Physica-Verlag Heidelberg.

OECD (2008). OECD Benchmark Definition of Foreign Direct Investment. $4^{\text {th }}$ edition 2008. Paris: OECD Publishing, p. 22.

Piklikiewicz, M. (ed.) (2001). Międzynarodowe stosunki gospodarcze na przełomie wieków. Warszawa: Difin.

Popovici, O., Călin, A. C. (2014). FDI Theories. A Location-based Approach. The Romanian Economic Journal, Vol. 17, p. 4-24. 
Rodrik, D., Velasco, A. (1999). Short-Term Capital Flows: 1-30. Available at: https://sites.hks.harvard.edu/m-rcbg/ research/d.rodrik_ksg_short.term.capital.flows.pdf. [Accessed August 16, 2018].

Rugman, A. M., Verbeke, A. (2008). Internalization Theory and Its Impact on the Field of International Business. In: Boddewyn, J. J., International Business Scholarship: AIB Fellows on the First 50 Years and Beyond, Research in Global Strategic Management, Vol. 14, p. 155-174. Emerald Group Publishing Limited.

Rymarczyk, J., Błaszczyk, M., Michalski, B., Niemiec, M., Niemiec, W., Wróblewski, M. (2008). Klimat inwestycyjny Dolnego Śląska w ocenie bezpośrednich inwestorów zagranicznych. Wrocław: Wydawnictwo Uniwersytetu Wrocławskiego.

Sahoo, P., Nataraj, G., Dash, R. K. (2014). Foreign Direct Investment in South Asia: Policy, Impact, Determinants and Challenges. New Delhi: Springer India.

Siddiqui, K. (2014). Flows of Foreign Capital into Developing Countries: A Critical Review. Journal of International Business and Economics, Vol. 2, No. 1, p. 29-46.

Siemiątkowski, P. (ed.) (2010). Międzynarodowe przepływy czynników produkcji. Toruń: Wydawnictwo Naukowe Uniwersytetu Mikołaja Kopernika, 116 p.

Simionescu, M. D. (2017). Determinants of Foreign Direct Investments in Bulgaria and Romania in the Context of Recent Economic Crisis. Academic Journal of Economic Studies, Vol. 3, No. 1, p. 68-72.

Smith, N. (2017). America Needs More Foreign Investment. Bloomberg View, 19 April.

Stephan, J. (2005). Technology Transfer via Foreign Direct Investment in Central and Eastern Europe: Theory, Method of Research and Empirical Evidence. New York: Palgrave Macmillan.

Tang, D. (2017). The Determinants of European Union (EU) Foreign Direct Investments in the EU Countries from Central and Eastern Europe During 1994-2012. Comparative Economic Research, Vol. 20, No. 1, p. 75-99.

Tülüce, N. S., Doğan, I. (2014). The Impact of Foreign Direct Investments on SMEs' Development. Procedia - Social and Behavioral Sciences, Elsevier, Vol. 150, p. 107-115.

UNCTAD. (2018). World Investment Report 2018. Investment and New Industrial Policies. Geneva: UNCTAD.

UNCTAD. (2014). World Investment Report 2014. Investing in the SDGs: An Action Plan. Geneva: UNCTAD.

UNCTAD. (2011). World Investment Report 2011. Non-Equity Modes of International Production and Development. Geneva: UNCTAD.

UNECE. (2004). Investment Climate: A UNECE Report. Prague: UNECE.

Vernon, R. (1966). International Investment and International Trade in the Product Cycle. Quarterly Journal of Economics, No. 80 (May), p. 190-207.

Visegrad Group. (2018). Available at: http://www.visegradgroup.eu/about [Accessed July 30, 2018].

Wei, Y., Balasubramanyam, V. N. (2005). Foreign Direct Investment: Six Country Case Studies. Northampton: Edward Elgar Publishing.

Wurgler, J., Baker, M., Foley, C. F. (2004). The Stock Market and Investment: Evidence from FDI Flows. NBER Working Series No. w10559. Cambridge: National Bureau of Economic Research.

Zekos, G. (2016). MNEs in the 21st Century. Hauppauge: Nova Science Publishers Inc.

\title{
VIŠ E GRA DO GRUPE் ISITRAUKIMAS I TARPTAUTINIO KAPITALO PERKËLIMĄ TIESIOGINIU UŽSIENIO INVESTICIJU FORMA POKRIZINIU LAIKOTARPIU
}

\author{
IWONA PAWLAS
}

Ekonomikos universitetas Katovicuose (Lenkija)

\section{Santrauka}

Tarptautinio kapitalo perkèlimas yra svarbus tarptautinių ekonominių santykių elementas. Tarptautinio kapitalo perkèlimo srautai atsiranda dèl traukiančiųų ir stumiančiųų veiksnių. Kapitalo srautai igauna gamybos kapitalo (nuosavybės finansavimo) ir kapitalo skolinimo bei skolinimosi (skolos finansavimo) formas. Be to, gamybos kapitalas suskirstytas ị netiesiogines ir tiesiogines užsienio investicijas. Straipsnyje 
daugiausia dèmesio skiriama tarptautiniam kapitalui perkelti tiesioginių užsienio investicijų (TUI) forma. TUI skatina tarptautinę ekonominę integraciją. Kapitalo ịplaukos TUI forma suvokiamos kaip ekonominio vystymosi skatinimo veiksnys, o tai ypač svarbu vadinamujų buvusių socialistinių šalių ekonomikai, tokia gali būti laikoma Višegrado grupès (V4) šalių ekonomika. Straipsnyje daugiausia dèmesio skiriama V4 šalių dalyvavimo tarptautinio kapitalo perkèlimo procesuose TUI forma.

Pagrindinis šio darbo tikslas - atskleisti V4 šalių investicinį patrauklumą, atsižvelgiant ị Tarptautinio rekonstrukcijos ir plètros banko, Pasaulio banko ataskaitas bei „Ernst ir Young“ apklausas. Lygiagretus tikslas - analizuoti V 4 šalių dalyvavimą tarptautinio kapitalo perkèlime tarptautinių užsienio investicijų (TUI) forma pokriziniu laikotarpiu bei TUI tiek vidaus, tiek išorès srautus ir atsargas.

Straipsnyje taikomi tyrimo metodai apima literatūros studijas, aprašomają ir lyginamają analizes. Atlikti tyrimai leidžia daryti bendrą išvadą, kad užsienio kapitalas vaidino svarbų vaidmenį transformuojant V4 ekonomiką ir integruojant V4 ị globalizuotą pasaulio ekonomiką. TUI ịplaukos leido papildyti kapitalo trūkumą ir didinti ekonominès veiklos efektyvumą. V4 šalių ịstojimas ị Europos Sajungą sudarẻ daug palankesnes sąlygas besivystančioms ekonomikoms įsitraukti ị tarptautinius kapitalo srautus. $2008 \mathrm{~m}$. pasaulinė finansų krizè šį procesą paveikè neigiamai. V4 šalys tebėra kapitalo grynosios importuotojos tiesioginių užsienio investicijų forma. Dèl gana pigios darbo jëgos Lenkijoje, Vengrijoje, Čekijoje ir Slovakijoje, V4 šalys pasirinktos kaip TUI vieta investuotojams, kurie sukuria gana daug darbo vietų. Per pastarajị dešimtmetị V4 šalių, kaip investuotojų, pozicija pasaulio rinkoje šiek tiek pakilo. Vis dèlto išorinių TUI akcijų dydis V4 šalyse vis dar kelis kartus viršija jų kapitalo investicijas ị pasaulio rinkas. Svarbūs dinamiški ir veiksmingi veiksmai, kuriais V4 būtų propaguojama kaip TUI vieta, kartu veiksmų, kurie skatintų V4 investicijas užsienyje.

PAGRINDINIAI ŽODŽIAI: tarptautinis kapitalo perkẻlimas, tiesioginès užsienio investicijos, Višegrado grupès (V4) šalys.

JEL KLASIFIKACIJA: F21, F23, F02, O57

Received: 2018.07.09

Revised: 2018.08 .09

Accepted: 2018.08 .20 